\title{
Inheritance of Resistance to Aspergillus Ear Rot and Aflatoxin Production of Corn from Tex6
}

\author{
A. M. Hamblin and D. G. White
}

First author: Department of Natural Resources and Environmental Sciences; and second author: Department of Crop Sciences, University of Illinois, Urbana 61801.

Accepted for publication 3 December 1999.

\begin{abstract}
Hamblin, A. M., and White, D. G. 2000. Inheritance of resistance to Aspergillus ear rot and aflatoxin production of corn from Tex6. Phytopathology 90:292-296.

The inheritance of resistance to Aspergillus ear rot and aflatoxin production in corn (Zea mays L.) caused by Aspergillus flavus was studied in progeny derived from crosses between the resistant corn inbred cv. Tex6 and susceptible inbred cvs. B73 and Mo17. From 1994 to 1996, plant generations included were the $\mathrm{P}_{1}$ (susceptible $\mathrm{B} 73$ or Mo17), $\mathrm{P}_{2}$ (resistant Tex6), $\mathrm{F}_{1}, \mathrm{~F}_{2}, \mathrm{~F}_{3}, \mathrm{BCP}_{1}, \mathrm{BCP}_{1}$-selfed, and $\mathrm{BCP}_{2}$. The $\mathrm{BCP}_{2}$-selfed generation was added in 1995 and 1996 for the B73 $\times$ Tex6 cross. Primary ears were pinboard inoculated and evaluated for Aspergillus ear rot severity. $F_{1}$ means deviated from the midparent value toward resistance
\end{abstract}

ABSTRACT

Preharvest infection of corn kernels by the fungus Aspergillus flavus Link:Fr. causes ear and kernel rot, resulting in reduced grain quality and potential aflatoxin contamination of grain. The greatest potential for disease development exists with hot and dry environments, insect damage to corn ears, and low levels of host resistance. Inheritance of resistance to Aspergillus ear rot and aflatoxin production in corn has been studied $(1,3-5,7,9,10,15,18$, 21-25). Most of these studies have focused on the evaluation of inbred cultivars (inbreds) and their hybrids using diallel mating designs. General combining ability is accepted as being more important for resistance to aflatoxin production than specific combining ability, which suggests additive gene action controlling resistance $(7,10,23,25)$. Very little information is available, however, which characterizes segregating populations for resistance to both Aspergillus ear rot and aflatoxin production (1).

This research was preceded by evaluation of available inbred germ plasm at the University of Illinois. Approximately 1,200 inbreds crossed with cvs. Mo17 or B73 were inoculated using a pinboard method, and 35 inbreds were identified for further study based on their level of resistance (2-5). Of the inbreds selected for further study, Tex6, derived from a southern cultivar (Plant Introduction [PI] number 401763), was consistently among the most resistant to both Aspergillus ear rot and aflatoxin production as an inbred and in crosses. The high level of resistance from Tex6 has been confirmed by others and the cultivar has been the subject of investigations into the physiological basis of resistance. Tex6 produces proteins that inhibit aflatoxin production and the growth of A. flavus in culture $(6,14)$. It also produces high levels of $\beta-1,3$-glucanase in kernels compared with the susceptible inbred B73 (19).

Corresponding author: A. M. Hamblin; E-mail address: hamblin@uiuc.edu

Publication no. P-2000-0126-01R

(C) 2000 The American Phytopathological Society for aflatoxin production and toward susceptibility for ear rot in both crosses. Analyses of generation means indicate that additive gene action was most important in the resistance to both ear rot and aflatoxin production in the B73 $\times$ Tex 6 cross. Mo17 was somewhat resistant to both traits, so resistance from Tex6 was not well defined in this cross. Broadsense heritabilities for ear rot and aflatoxin production were 58 and $63 \%$ for Mo17 × Tex6, and 66 and $65 \%$ for B73 $\times$ Tex6. Narrow-sense heritabilities for ear rot and aflatoxin production were 39 and $45 \%$ for B73 $\times$ Tex6. It is estimated that one cycle of selection for resistance within B73 $\times$ Tex $6 \mathrm{~F}_{3}$ families would reduce the percentage of ear rot severity by $8.5 \%$ and aflatoxin concentration by $19 \mathrm{ng} / \mathrm{g}$.

Additional keywords: maize, mycotoxin.

A previous study on inheritance of resistance from Tex6 dealt primarily with ear rot (4). The inheritance of resistance to aflatoxin production also needs to be studied because previous research found a poor relationship between Aspergillus ear rot and aflatoxin production $(1,4,16)$. Tex6 has poor agronomic characteristics and is not currently used in commercial germ plasm as a source of resistance. It will have greater value to breeders after resistance has been transferred into an agronomically acceptable background. This can be accomplished by crossing resistance from Tex6 into commercially acceptable B73- or Mo17-related inbreds. This gene transfer will be more efficient with information on inheritance of resistance. The objectives of this research were to determine the gene action conditioning resistance to Aspergillus ear rot and aflatoxin production from Tex6, estimate heritabilities, and predict gain from selection. In order to achieve this objective, we chose to use two different susceptible parents with a larger number of more advanced selfed progenies.

\section{MATERIALS AND METHODS}

The generations evaluated for the Mo17 × Tex6 cross in 1994 and 1995 were the $\mathrm{P}_{1}$ (Mo17), $\mathrm{P}_{2}$ (Tex6), $\mathrm{F}_{1}, \mathrm{~F}_{2}, \mathrm{~F}_{3}, \mathrm{BCP}_{1}, \mathrm{BCP}_{2}$, and $\mathrm{BCP}_{1}$-selfed generations. The generations evaluated for the $\mathrm{B} 73 \times$ Tex6 cross in 1995 and 1996 were the $\mathrm{P}_{1}$ (B73), $\mathrm{P}_{2}$ (Tex6), $\mathrm{F}_{1}, \mathrm{~F}_{2}, \mathrm{~F}_{3}, \mathrm{BCP}_{1}, \mathrm{BCP}_{2}, \mathrm{BCP}_{1}$-selfed, and $\mathrm{BCP}_{2}$-selfed generations. The $\mathrm{F}_{1}, \mathrm{~F}_{2}, \mathrm{~F}_{3}, \mathrm{BCP}_{1}, \mathrm{BCP}_{2}, \mathrm{BCP}_{1}$-selfed, and $\mathrm{BCP}_{2}$-selfed generations were produced by crossing the parental inbred lines, selfing individual $F_{1}$ plants, selfing individual $F_{2}$ plants, crossing the $F_{1}$ to the susceptible parent, crossing the $F_{1}$ to the resistant parent, selfing the $\mathrm{BCP}_{1}$ generation, and selfing the $\mathrm{BCP}_{2}$ generation, respectively. Plots were planted in rows $5.34 \mathrm{~m}$ long spaced $0.76 \mathrm{~m}$ apart with 24 plants per row. A randomized complete block design was used with three replications of all generations. In all experiments, families were planted ear-to-row for each generation with as many of the families as possible being represented 
both years. Each replication in 1994 for the Mo17 $\times$ Tex 6 cross consisted of 2 rows of $\mathrm{P}_{1}, \mathrm{P}_{2}$, and $\mathrm{F}_{1}$ generations; 7 rows of $\mathrm{F}_{2}$, $\mathrm{BCP}_{1}$, and $\mathrm{BCP}_{2}$ generations; 209 rows of $\mathrm{F}_{3}$ families; and 36 rows of $\mathrm{BCP}_{1}$-selfed families. In 1995, 15 rows of $\mathrm{P}_{1}$ (Mo17), $\mathrm{P}_{2}$ (Tex6), $\mathrm{F}_{1}, \mathrm{~F}_{2}, \mathrm{BCP}_{1}$, and $\mathrm{BCP}_{2}$ generations; 199 rows of $\mathrm{F}_{3}$ families; and 33 rows of $\mathrm{BCP}_{1}$-selfed families. The 1995 experiment had fewer $\mathrm{F}_{3}$ and $\mathrm{BCP}_{1}$-selfed families because of lack of seed of some families. Each replication in 1995 for the $\mathrm{B} 73 \times$ Tex6 cross included 15 rows of the $\mathrm{P}_{1}, \mathrm{P}_{2}, \mathrm{~F}_{1}, \mathrm{~F}_{2}, \mathrm{BCP}_{1}$, and $\mathrm{BCP}_{2}$ generations; 123 rows of $\mathrm{F}_{3}$ families; 162 rows of $\mathrm{BCP}_{1}$-selfed families; and 172 rows of $\mathrm{BCP}_{2}$-selfed families. More families were included in 1996 to provide better estimates of means and variances. In 1996, 30 rows of the $\mathrm{P}_{1}$ and $\mathrm{P}_{2}$ generations, 15 rows of the $\mathrm{F}_{1}, \mathrm{~F}_{2}, \mathrm{BCP}_{1}$, and $\mathrm{BCP}_{2}$ generations; 280 rows of $\mathrm{F}_{3}$ families; 339 rows of $\mathrm{BCP}_{1}$-selfed families; and 124 rows of $\mathrm{BCP}_{2}$-selfed families. Experiments were planted 17 May 1994, 5 May 1995, and 22 May 1996 at the University of Illinois Agronomy/Plant Pathology South Farm, Urbana.

Isolates used, inoculum preparation, and inoculation were the same as previously reported (1). Rows were harvested 50 to 60 days after midsilk, and ears were dried in a forced-air dryer for 3 days. Individual ears were rated on the percentage of the inoculated area rotted by A. flavus. Poorly inoculated ears were discarded.

Bulked ears from each row were shelled and ground for aflatoxin extraction followed by quantification using an indirect com- petitive enzyme-linked immunosorbent assay (ELISA) (3). A total of $1 \mathrm{~g}$ of ground grain was used in the analysis instead of the prescribed $0.5 \mathrm{~g}$. Samples were read with a microplate reader (model4000, Dynatech Laboratories, Chantilly, VA) at $490 \mathrm{~nm}$. The lower detection limit using this procedure is $2 \mathrm{ng}$ of aflatoxin $\mathrm{B}_{1}$ per $\mathrm{g}$, so samples with nondetectable aflatoxin were recorded as $2 \mathrm{ng} / \mathrm{g}$.

For generation mean analysis, ear rot means were calculated for each row and then averaged by generation within each replication. Aflatoxin values of bulked ears from individual rows were averaged by generation within each replication. Ear rot and aflatoxin data were analyzed as a randomized complete block design using the SAS general linear model procedure (SAS Institute, Cary, NC). Blocks within years, generations, and generations by years were considered random effects. Aflatoxin values were transformed using a $\log _{e}$ function to homogenize the variances between generations. Deviations of the $F_{1}$ means from the calculated midparent values (the average of the two parents) were tested using $z$ values for the equality of the two population means within each year. Generation mean analysis followed Hayman's method $(12,13)$ and Gamble's notations (8) given by: $m=$ mean based on $\mathrm{F}_{2}, a=$ pooled additive effects, and $d=$ pooled dominant effects. Potence ratios were calculated by dividing the dominant parameter estimate for the slope by the additive parameter estimate for ear rot and aflatoxin from each cross (17).

TABLE 1. Aspergillus ear rot and aflatoxin means of various generations from crosses between corn cvs. Mo17 × Tex6 and B73 × Tex6 evaluated in Urbana, IL, from 1994 to 1996

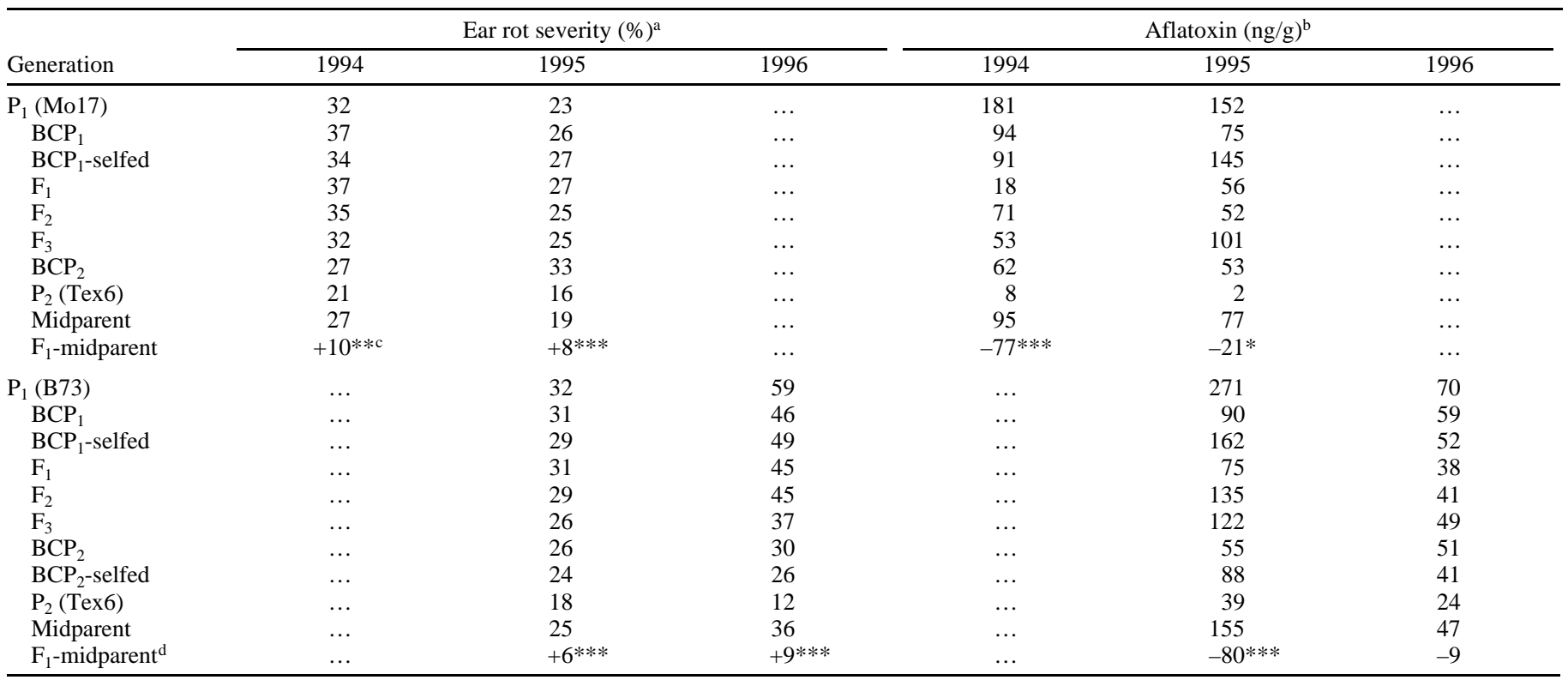

${ }^{a}$ Measured as the percentage of the ear infected by Aspergillus flavus. All values are a mean of three replications.

${ }^{\mathrm{b}}$ Measured by indirect competitive enzyme-linked immunosorbent assay. Samples were run in triplicate.

c *,**, and $* * *$ indicate significance at $P=0.05,0.01$, and 0.001 , respectively.

${ }^{\mathrm{d}}$ Deviations of $\mathrm{F}_{1}$ means from the calculated midparent values (average of the two parents) were tested, using $z$ values for the equality of the two population means within each year.

TABLE 2. Analysis of variance of mean Aspergillus ear rot and $\log _{e}$-transformed aflatoxin production for generations from crosses between corn cvs. Mo17 $\times$ Tex6 and B73 × Tex6 evaluated in Urbana, IL, from 1994 to $1996^{\mathrm{a}}$

\begin{tabular}{|c|c|c|c|c|c|c|}
\hline \multirow[b]{2}{*}{ Source } & \multicolumn{3}{|c|}{ Mo17 × Tex6 (1994-1995) } & \multicolumn{3}{|c|}{ В73 × Тex6 (1995-1996) } \\
\hline & $\mathrm{df}$ & Ear rot (MS) & Aflatoxin (MS) & df & Ear rot (MS) & Aflatoxin (MS) \\
\hline Year & 1 & $507.00 * *$ & 0.54 & 1 & $1,745.35^{* *}$ & $7.85^{* *}$ \\
\hline Block (year) & 4 & 4.75 & 0.62 & 4 & 2.07 & $0.37 *$ \\
\hline Additive & 1 & $304.69^{*}$ & $47.49 * * *$ & 1 & $3,514.01 * * *$ & $6.97 * * *$ \\
\hline Dominance & 1 & $409.21 *$ & 0.49 & 1 & 270.68 & 0.35 \\
\hline Residual & 5 & 23.09 & 3.81 & 6 & 22.26 & 0.24 \\
\hline
\end{tabular}

${ }^{\mathrm{a}} \mathrm{MS}=$ mean squares; $*{ }^{* *}$, and $* * *$ indicate significance at $P=0.05,0.01$, and 0.001 , respectively $(F$ test $) ; \mathrm{CV}=$ coefficient of variation. 
Spearman's correlation coefficients were calculated between ear rot ratings and aflatoxin values for the $\mathrm{F}_{3}$ and $\mathrm{BCP}_{1}$-selfed families for the Mo17 $\times$ Tex6 cross and $\mathrm{F}_{3}, \mathrm{BCP}_{1}$-selfed, and $\mathrm{BCP}_{2^{-}}$ selfed families for the $\mathrm{B} 73 \times$ Tex 6 cross. Within each generation analyzed, the year average for each family was used in the analysis for both ear rot and aflatoxin production.

Broad-sense heritabilities were estimated on a progeny mean basis of $\mathrm{F}_{3}$ families by

$$
h^{2}=\sigma_{g}^{2} /\left[\left(\sigma_{p}^{2} / r y\right)+\left(\sigma_{g y}^{2} / y\right)+\sigma_{g}^{2}\right]
$$

where $r, y, \sigma_{g}^{2}, \sigma_{p}^{2}$, and $\sigma_{g y}^{2}$ represent the number of replicates and years, the genetic variance component, the phenotypic variance component, and the variance component due to genotype $\times$ year, respectively (11). Narrow-sense heritabilities for the B73 $\times$ Tex6 cross were determined from genetic expectations for the $\mathrm{BCP}_{1^{-}}$ selfed, $\mathrm{BCP}_{2}$-selfed, and $\mathrm{F}_{3}$ populations based on a reduced data set of those families that were present in both years (11). Additive genetic variance was estimated by

$$
\sigma_{A}^{2}=2 \sigma_{g \mathrm{~F}_{3}}^{2}-\sigma_{\text {BCP1-selfed }}^{2}-\sigma_{\text {BCP1-selfed }}^{2}
$$

where $\sigma_{{ }_{2 \mathrm{~F}}}^{2}, \sigma_{\mathrm{BCP1} \text {-selfed, }}^{2}$, and $\sigma_{\mathrm{BCP} 2 \text {-selfed }}^{2}$ are variances estimated for the $\mathrm{F}_{3}, \mathrm{BCP}_{1}$-selfed, and $\mathrm{BCP}_{2}$-selfed generations, respectively. The SAS general linear models procedure was used to obtain variance components for the effects of years, blocks within years, families, and families by years. All effects were considered random except the year. Estimates for aflatoxin production were determined from $\log _{\mathrm{e}}$ transformed means. The predicted gain from selection was calculated from the formula

$$
G_{s}=i\left(\sqrt{\sigma_{p}^{2}}\right)\left(h_{n}^{2}\right)
$$

where $G_{s}$ is the predicted genetic advance, $i$ is a constant based on selection intensity in standard deviation units, $\sqrt{\sigma_{p}^{2}}$ is the square root of the phenotypic variance, and $h_{n}^{2}$ is the narrow-sense heritability of the quantitative character being evaluated (20). A $20 \%$ selec-

TABLE 3. Percentage of variation in ear rot and $\log _{e}$-transformed aflatoxin production among corn generation means accounted for by additive, dominant, and residual gene effects

\begin{tabular}{lccc}
\hline & \multicolumn{3}{c}{ \% Gene effect } \\
\cline { 2 - 4 } Cross, trait & Additive & Dominant & Residual \\
\hline Mo17 $\times$ Tex6, ear rot & 36.7 & 49.3 & 13.9 \\
Mo17 $\times$ Tex6, aflatoxin & 76.5 & 5.2 & 18.2 \\
B73 $\times$ Tex6, ear rot & 89.7 & 6.9 & 3.4 \\
B73 $\times$ Tex6, aflatoxin & 69.6 & 14.8 & 15.7 \\
\hline
\end{tabular}

tion intensity $(i=1.4)$ and $\log _{e}$ transformed aflatoxin means and variances were used for this calculation.

\section{RESULTS}

Aspergillus ear rot. Ear rot severity in 1994 for Mo17 × Tex6 generations was greater than in 1995 (Table 1). Likewise, ear rot severity in 1996 for B73 × Tex6 generations was greater than 1995 . In 1995, conditions during August and September were very dry and growth of $A$. flavus was poor in the inoculated area of the ears. The $F_{1}$ generation means were significantly higher than midparent values in both crosses over both years. The analysis of generation means indicated a significant year effect for both Mo17 × Tex6 and B73 $\times$ Tex 6 crosses (Table 2). Dominant gene effects for susceptibility were relatively important for Mo17 × Tex6 but not for B73 $\times$ Tex6 (Tables 2 and 3). Potence ratios, $(d) /(a)$, were +2.10 for the Mo17 cross and +0.55 for B73, suggesting that the sum effect of the alleles for susceptibility exhibit overdominance and partial dominance, respectively, to the sum effect of the alleles for resistance (Table 4). Broad-sense heritabilities were $58 \%$ for the Mo17 cross and 66\% for B73 (Table 5). Narrow-sense heritability for the B73 cross was $39 \%$. One cycle of selection for ear rot resistance in $\mathrm{B} 73 \times$ Tex $6 \mathrm{~F}_{3}$ families would reduce ear rot severity by an estimated $8.5 \%$ of the ear rot rating.

Aflatoxin production. Aflatoxin production was greatest in 1994 and 1995, when warm temperatures occurred after inoculation. In

TABLE 5. Relationship between Aspergillus ear rot and aflatoxin production

\begin{tabular}{|c|c|c|c|}
\hline $\begin{array}{l}\text { Cross } \\
\text { Year }\end{array}$ & Population & $\begin{array}{c}\text { No. of } \\
\text { observations }\end{array}$ & $\begin{array}{l}\text { Spearman's } \\
\text { correlation }^{\text {a }}\end{array}$ \\
\hline \multicolumn{4}{|c|}{ Mo17 × Тех6 } \\
\hline \multirow[t]{2}{*}{1994} & $\mathrm{BCP}_{1}$-selfed & 36 & $0.36^{*}$ \\
\hline & $\mathrm{F}_{3}$ & 167 & 0.04 \\
\hline \multirow[t]{2}{*}{1995} & $\mathrm{BCP}_{1}$-selfed & 31 & -0.11 \\
\hline & $\mathrm{F}_{3}$ & 167 & $0.22 * *$ \\
\hline \multicolumn{4}{|c|}{ В73 × Тex 6} \\
\hline \multirow[t]{3}{*}{1995} & $\mathrm{BCP}_{1}$-selfed & 146 & 0.11 \\
\hline & $\mathrm{BCP}_{2}$-selfed & 124 & $0.24 * *$ \\
\hline & $\mathrm{F}_{3}$ & 102 & $0.21 *$ \\
\hline \multirow[t]{3}{*}{1996} & $\mathrm{BCP}_{1}$-selfed & 146 & -0.03 \\
\hline & $\mathrm{BCP}_{2}$-selfed & 124 & 0.05 \\
\hline & $\mathrm{F}_{3}$ & 102 & -0.04 \\
\hline
\end{tabular}
in the corn crosses Mo17 × Tex6 and B73 × Tex6 evaluated in Urbana, IL, from 1994 to 1996

\begin{tabular}{|c|c|c|c|c|c|c|}
\hline $\begin{array}{l}\text { Cross } \\
\text { Trait }\end{array}$ & Parameter $^{\mathrm{a}}$ & $\begin{array}{l}\text { Potence ratio } \\
\qquad[(d) /(a)]\end{array}$ & $\begin{array}{l}\text { Parameter } \\
\text { estimate }\end{array}$ & $\begin{array}{l}\text { Standard } \\
\text { error }\end{array}$ & $\begin{array}{c}t \text { for } \mathrm{H} 0^{\mathrm{b}}: \\
\text { parameter }=0\end{array}$ & $P>|T|$ \\
\hline \multicolumn{7}{|l|}{ Mo17 × Тex6 } \\
\hline \multirow[t]{3}{*}{ Ear rot } & $m$ & & 29.41 & \pm 0.82 & 35.75 & 0.0001 \\
\hline & $a$ & +2.10 & 4.54 & \pm 1.30 & 3.49 & 0.0011 \\
\hline & $d$ & & 9.55 & \pm 2.48 & 3.85 & 0.0004 \\
\hline \multirow[t]{3}{*}{ Aflatoxin } & $m$ & & 37.78 & \pm 12.98 & 2.91 & 0.0056 \\
\hline & $a$ & -0.50 & 57.35 & \pm 8.32 & 6.89 & 0.0001 \\
\hline & $d$ & & -28.91 & \pm 15.84 & -1.83 & 0.0748 \\
\hline \multicolumn{7}{|l|}{ B $73 \times$ Тex 6} \\
\hline \multirow[t]{3}{*}{ Ear rot } & $m$ & & 34.20 & \pm 1.26 & 27.14 & 0.0001 \\
\hline & $a$ & +0.55 & 13.97 & \pm 1.97 & 7.09 & 0.0001 \\
\hline & $d$ & & 7.68 & \pm 3.90 & 1.97 & 0.0545 \\
\hline \multirow[t]{3}{*}{ Aflatoxin } & $m$ & & 4.12 & \pm 0.09 & 48.23 & 0.0001 \\
\hline & $a$ & -0.45 & 0.62 & \pm 0.13 & 4.66 & 0.0001 \\
\hline & $d$ & & -0.28 & \pm 0.26 & -1.04 & 0.3017 \\
\hline
\end{tabular}

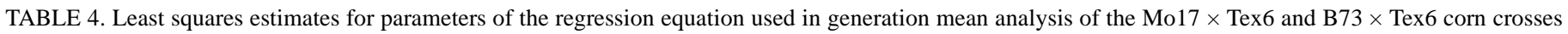
evaluated for Aspergillus ear rot and aflatoxin production in Urbana, IL, from 1994 to 1996

${ }^{\mathrm{a}} m=$ mean; $a=$ additive gene effect; and $d=$ dominant gene effect.

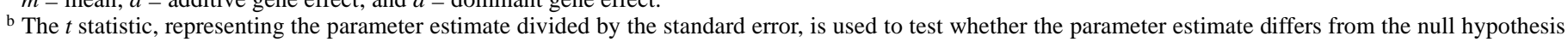
that the coefficient is equal to 0 . 
general, August and September of 1996 were much cooler, and aflatoxin production was much lower (Table 1). $F_{1}$ means were significantly lower than midparent values in all cases except for the B73 crosses in 1996, when aflatoxin production was much lower. Analysis of generation means indicated a significant difference between years for B73 × Tex6 generations in 1995 and 1996 but not for Mo17 × Tex6 generations in 1994 and 1995. Additive gene action was responsible for the variation between generation means in both crosses (Tables 2 and 3). Additive gene effects were most important for resistance. Potence ratios, $(d) /(a)$, were -0.50 for the Mo17 cross and -0.45 for B73, suggesting that the sum effect of the alleles for resistance is partially dominant to the sum effect of the alleles for susceptibility (Table 4). Broad-sense heritabilities were $63 \%$ for the Mo17 cross and 65\% for B73 (Table 5). Narrow-sense heritability for the B73 cross was $45 \%$. One cycle of selection for resistance to aflatoxin production in B73 $\times$ Tex6 $\mathrm{F}_{3}$ families would reduce the aflatoxin concentration by an estimated $19 \mathrm{ng} / \mathrm{g}$. Significant relationships between aflatoxin production and ear rot were rare in the $\mathrm{F}_{3}$ and backcrossed generations (Table 6).

\section{DISCUSSION}

Generation mean analysis is useful for identifying the types of gene action conditioning a particular trait, if the parents used adequately represent both extremes of the trait being evaluated. In disease-resistance studies, the analysis of generation means assumes that the susceptible parent is completely susceptible, lacking genes necessary to provide resistance, and the resistant parent has genes necessary to express resistance. In this study, B73 was susceptible to both ear rot and aflatoxin production, making it useful as a susceptible parent. Mo17 has a moderate level of resistance to Aspergillus ear rot, which can obscure the genetic information obtained about the resistance from Tex6. Other inbreds with even greater susceptibility could have been used; however, B73 was chosen because of its relationship to commercially used germ plasm.

Dominant gene effects for susceptibility to ear rot were indicated from the analysis of generation means for the Mo17 × Tex6 cross, which agrees with a previous study that also used Mo17 as the susceptible parent (3). However, dominant gene effects in the B73 $\times$ Tex6 cross were not significant. Possible interactions may be involved in the cross with Mo17 because of the contribution of

TABLE 6. Analysis of variance of $\mathrm{F}_{3}, \mathrm{BCP}_{1}$-selfed, and $\mathrm{BCP}_{2}$-selfed family progeny means for Aspergillus ear rot and $\log _{e}$-transformed aflatoxin production for generations from a cross between corn cvs. B73 and Tex6 evaluated in Urbana, IL, in 1995 and 1996, and heritability estimates calculated from variance components of segregating generations ${ }^{\mathrm{a}}$

\begin{tabular}{|c|c|c|c|c|}
\hline \multirow[b]{2}{*}{ Source $^{b}$} & \multicolumn{2}{|c|}{ Ear rot } & \multicolumn{2}{|c|}{ Aflatoxin } \\
\hline & $\mathrm{df}$ & MS & $\mathrm{df}$ & MS \\
\hline Year & 1 & $95,591 * *$ & 1 & 26.75 \\
\hline Block (year) & 4 & $4,050 * * *$ & 4 & $7.57 * *$ \\
\hline Generation & 2 & $50,080 * * *$ & 2 & $60.54 * * *$ \\
\hline Generation $\times$ year & 2 & $26,232 * * *$ & 2 & $17.80 * * *$ \\
\hline \multicolumn{5}{|l|}{ Entry } \\
\hline Among $\mathrm{F}_{3}$ & 103 & 247 & 102 & 2.71 \\
\hline Among $\mathrm{BCP}_{1}$-selfed & 145 & 258 & 147 & 2.07 \\
\hline Among $\mathrm{BCP}_{2}$-selfed & 123 & 155 & 123 & 2.20 \\
\hline Entry $\times$ year & 145 & $203 *$ & 147 & 2.22 \\
\hline Pooled error & 1,718 & 164 & 1,721 & 1.98 \\
\hline $\mathrm{CV}$ & $\ldots$ & $38 \%$ & $\ldots$ & $40 \%$ \\
\hline$h^{2}$ & $\ldots$ & $66 \%$ & $\ldots$ & $65 \%$ \\
\hline$h_{n}^{2}$ & $\ldots$ & $39 \%$ & $\ldots$ & $45 \%$ \\
\hline
\end{tabular}

${ }^{a} \mathrm{MS}=$ mean squares; $*, * *$, and $* * *$ indicate significance at $P=0.05,0.01$, and 0.001 , respectively $(F$ test).

${ }^{\mathrm{b}} \mathrm{CV}=$ coefficient of variation; $h^{2}=$ broad-sense heritabilities calculated on a progeny mean basis of $\mathrm{F}_{3}$ families; and $h_{n}^{2}=$ narrow-sense heritabilities calculated from estimates of additive variance from $\mathrm{F}_{3}, \mathrm{BCP}_{1}$-selfed, and $\mathrm{BCP}_{2^{-}}$ selfed populations. resistant alleles from both Tex6 and Mo17. Resistance to aflatoxin production from Tex6 is primarily additive in inheritance, which is similar to genetic effects conferred from the inbred LB31 (1). Potence ratios and $F_{1}$ means relative to the calculated midparent value indicate some dominance.

Broad-sense heritabilities for Mo17 × Tex6 ear rot $(58 \%)$ were slightly higher than previously reported (47\%) (4). Broad-sense heritabilities for aflatoxin production in the B73 $\times$ Tex 6 cross $(65 \%)$ were comparable to those reported for the B73 $\times$ LB3 1 cross (66\%) (1). The inclusion of selfed backcrosses to both parents allowed the calculation of additive genetic variance for estimation of narrow-sense heritabilities and gain from selection. Heritability, which is the proportion of total variability accounted for by genetic variance, was high, even though variation among families in the combined analysis was not significant. The lack of significance among families in the combined analysis for ear rot and aflatoxin production was due to poor separation of values in one of two years, due to unfavorable environmental conditions.

Perhaps the greatest barrier to breeding for resistance to Aspergillus ear rot and aflatoxin production is the considerable amount of variation that may exist between years. In some years, environmental conditions favor aflatoxin production. In those years, selection of resistance based on aflatoxin production will allow for progress. Unfortunately, in those years when aflatoxin production is low and the range of values not great enough to be useful in selection, selection for ear rot alone may not be advisable. This is because of the poor correlation between ear rot and aflatoxin production found in this study and others $(1,3,4)$. Considerable variation between years emphasizes the value of genetic markers which would allow selection of resistant genotypes in the absence of reliable phenotypic data. In those years where a broad range in both ear rot severity and aflatoxin production is observed, selection of resistant genotypes may be very profitable. However, this is not always the case.

\section{ACKNOWLEDGMENTS}

Research support was provided by USDA-CSRS grants AG-94-342150023 and AG-58-3620-0-003. We thank M. Lovekamp, P. Schall, and D. Severns for their assistance in aflatoxin assays.

\section{LITERATURE CITED}

1. Campbell, K. W., Hamblin, A. M., and White, D. G. 1997. Inheritance of resistance to aflatoxin production in the cross between corn inbreds B73 and LB31. Phytopathology 87:1144-1147.

2. Campbell, K. W., and White, D. G. 1994. An inoculation device to evaluate maize for resistance to ear rot and aflatoxin production by Aspergillus flavus. Plant Dis. 78:778-781.

3. Campbell, K. W., and White, D. G. 1995. Evaluation of corn genotypes for resistance to Aspergillus ear rot, kernel infection, and aflatoxin production. Plant Dis. 79:1039-1045.

4. Campbell, K. W., and White, D. G. 1995. Inheritance of resistance to Aspergillus ear rot and aflatoxin in corn genotypes. Phytopathology 85: 886-896.

5. Campbell, K. W., White, D. G., Toman, J., and Rocheford, T. R. 1993. Sources of resistance in $\mathrm{F}_{1}$ corn hybrids to ear rot caused by Aspergillus flavus. Plant Dis. 77:1169.

6. Chen, Z.-Y., Brown, R. L., Lax, A. R., Zuo, B. Z., Cleveland, T. E., and Russin, J. S. 1997. Resistance to Aspergillus flavus in corn kernels is associated with a 14-kDa protein. (Abstr.) Phytopathology 87(suppl.):S19.

7. Darrah, L. L., Lillehoj, E. B., Zuber, M. S., Scott, G. E., Thompson, D., West, D. R., Widstrom, N. W., and Fortnum, B. A. 1987. Inheritance of aflatoxin $\mathrm{B}_{1}$ levels in maize kernels under modified natural inoculation with Aspergillus flavus. Crop Sci. 27:869-872.

8. Gamble, E. E. 1962. Gene effects in corn (Zea mays L.) I. Separation of relative importance of gene effects for yield. Can. J. Plant Sci. 42:339-348.

9. Gardner, C. A. C., Darrah, L. L., Zuber, M. S., and Wallin, J. R. 1987. Genetic control of aflatoxin production in maize. Plant Dis. 71:426-429.

10. Gorman, D. P., Kang, M. S., Cleveland, T., and Hutchinson, R. L. 1992. Combining ability for resistance to field aflatoxin accumulation in maize grain. Plant Breed. 109:292-303. 
11. Hallauer, A. R., and Miranda, J. B. 1988. Quantitative Genetics in Maize Breeding, 2nd ed. Iowa State University Press, Ames.

12. Hayman, B. I. 1958. The separation of epistatic from additive and dominance variation in generation means. Heredity 12:371-390.

13. Hayman, B. I. 1960. The separation of epistatic from additive and dominance variation in generation means II. Genetics 31:133-146.

14. Huang, Z. Y., White, D. G., and Payne, G. A. 1997. Corn seed proteins inhibitory to Aspergillus flavus and aflatoxin biosynthesis. Phytopathology 87:622-627.

15. Kang, M. S., Lillehoj, E. B., and Widstrom, N. W. 1990. Field aflatoxin contamination of maize genotypes of broad genetic base. Euphytica 51: 19-23.

16. Kaufman, B., Campbell, K. W., White, D. G., and Rocheford, T. R. 1995. Maize RFLPs associated with resistance to fungal growth and aflatoxin production. Pages 174-175 in: Agronomy Abstracts. American Society of Agronomy, Madison, WI.

17. Kearsey, M. J., and Pooni, H. S. 1996. The Genetical Analysis of Quantitative Traits. Chapman and Hall, London.

18. Lillehoj, E. B., Kwolek, W. F., Vandegraft, E. E., Zuber, M. S., Calvert, O. H., Widstrom, N., Futrell, M. C., and Bockholt, A. J. 1975. Aflatoxin production in Aspergillus flavus-inoculated ears of corn grown at diverse locations. Crop Sci. 15:267-270.

19. Lozovaya, V. V., Waranyuwat, A., and Widholm, J. M. 1998. $\beta-1,3-G l u-$ canase and resistance to Aspergillus flavus infection in maize. Crop Sci. 38:1255-1260

20. Poehlman, J. M., and Sleper, D. A. 1995. Breeding Field Crops, 4th ed. Iowa State University Press, Ames.

21. Scott, G. E., and Zummo, N. 1988. Sources of resistance in maize to kernel infection by Aspergillus flavus in the field. Crop Sci. 28:504-507.

22. Tucker, D. H., Trevathan, L. E., King, S. B., and Scott, G. E. 1986. Effect of four inoculation techniques of infection and aflatoxin concentration of resistant and susceptible corn hybrids inoculated with Aspergillus flavus. Phytopathology 76:290-293.

23. Widstrom, N. W., McMillian, W. W., and Wilson, D. M. 1987. Segregation for resistance to aflatoxin contamination among seeds on an ear of hybrid maize. Crop Sci. 27:961-963.

24. Widstrom, N. W., Wilson, D. M., and McMillian, W. W. 1984. Ear resistance of maize inbreds to field aflatoxin contamination. Crop Sci. 24:11551157.

25. Zuber, M. S., Calvert, O. H., Kwolek, W. F., Lillehoj, E. B., and Kang, M. S. 1978. Aflatoxin $B_{1}$ production in an eight-line diallel of Zea mays infected with Aspergillus flavus. Phytopathology 68:1346-1349. 